\title{
IMPACT OF THE WEB APPLICATION FOR THE EDUCATIONAL PROCESS ON THE COMPOUND INTEREST CONSIDERING DATA SCIENCE
}

\author{
Dr. Ricardo-Adan SALAS-RUEDA \\ ORCID: 0000-0002-4188-4610 \\ Instituto de Ciencias Aplicadas y Tecnologia, \\ Universidad Nacional Autonoma de Mexico \\ Mexico City, MEXICO \\ Dr. Erika-Patricia SALAS-RUEDA \\ ORCID: 0000-0002-9144-6432 \\ Instituto Tecnologico y de Estudios Superiores de Monterrey \\ Mexico City, MEXICO \\ Rodrigo-David SALAS-RUEDA \\ ORCID: 0000-0002-2598-2042 \\ Universidad Autonoma Metropolitana \\ Mexico City, MEXICO
}

Received: 28/08/2019 Accepted: 12/03/2020

\begin{abstract}
This quantitative research analyzes the impact of the Web Application for the Educational Process on Compound Interest (WAEPCI) considering the machine learning and data science. The sample is composed of 46 students who studied the Financial Mathematics course in a Mexican university during the 2017 school year. WAEPCI presents the calculation of the Compound Interest and Compound Amount over a period of four years through the data simulation. The results of the machine learning (linear regression) indicate that WAEPCI positively influences the assimilation of knowledge and development of mathematical skills on the Compound Interest and Compound Amount. Data science establishes 4 predictive models on the use of WAEPCI in the educational process by means of the decision tree technique. The construction of web applications facilitates the active role of students, improves the assimilation of knowledge and allows the development of skills. Finally, WAEPCI improves the teaching-learning conditions on Financial Mathematics through the data simulation.
\end{abstract}

Keywords: Technology, higher education, web application, machine learning, data science.

\section{INTRODUCTION}

Technology is transforming the planning and organization of school activities through the construction and use of virtual spaces for learning and teaching (Gezgin, 2019; Mishra \& Iyer, 2015; Yeoman \& Ashmore, 2018). In particular, Information and Communication Technologies (ICT) are modifying the behavior of teachers and students during the educational process (Blaine, 2019; Lee, Yeung \& Cheung, 2019; Mei \& May, 2018).

Educational institutions must update pedagogical strategies through digital tools in order to meet the needs and demands of students (Carvalho \& Yeoman, 2018; Rooney \& Nystrom, 2018; Zeivots \& Schuck, 2018). The use of technology such as videos, audiovisual contents and digital tools allows achieving the active role of students during the learning process (Le \& Pinkwart, 2015). 
Young teachers are more frequently using technological tools in the educational process because these individuals have developed digital skills (Ayale-Perez \& Joo-Nagata, 2019). For example, Facebook improved communication and participation among students through the dissemination of school activities (SalasRueda \& Salas-Rueda, 2019).

In fact, the incorporation of web applications in the classroom positively influences the teaching-learning process (Jack \& Higgins, 2019; Scardamalia \& Bereiter, 2014). Due to technological advances, teachers have the possibility to use a wide variety of educational applications on the Internet (Hughes \& Dobbins, 2015; Marcel, 2019; Spector, 2014). For example, interactive multimedia systems and mobile applications favor the active role of students during the learning process (Bdiwi, Runz, Faiz, \& Cherif, 2019).

One of the educational challenges in the 21 st century is the creation of virtual spaces to improve teachinglearning conditions (Bidarra \& Rusman, 2017; Doney, 2019). Therefore, this quantitative research proposes the construction of WAEPCI to improve teaching-learning conditions on financial mathematics.

The research questions are:

- What is the impact of WAEPCI on the assimilation of knowledge and development of mathematical skills on Compound Interest and Compound Amount?

- What are the predictive models on the use of WAEPCI in the teaching-learning process?

\section{WEB APPLICATIONS IN THE EDUCATIONAL FIELD}

The educational institutions are modifying the curricula in order to develop the competences of students through the technological tools (Herodotou, Heiser, \& Rienties, 2017; Marshalsey \& Sclater, 2018). In particular, universities face the challenge of improving the teaching-learning conditions through the construction of new virtual spaces (Marcel, 2019; Wang \& Wang, 2017).

Web applications positively influence the participation of students during the educational process and encourage new ways to achieve the learning (Blaine, 2019; Zeivots \& Schuck, 2018). In particular, Bdiwi, Runz, Faiz and Cherif (2019) propose to improve the educational process through the use of sensors, smart devices, web applications and Internet services.

The digital tools facilitate the planning and realization of educational activities centered on students (Mei \& May, 2018). In fact, Internet is changing the functions and roles of teachers through the sending and receiving of information on the network (Ramadan, 2016).

\section{Use and Construction of Web Applications}

The design and construction of web applications is changing the way of carrying out the school activities (Mei \& May, 2018). In particular, Salas-Rueda, Salas-Rueda, Salas-Rueda and Vargas-Perez (2019) designed a web application to facilitate the assimilation of knowledge during the educational process of statistics. Likewise, Noguchi, Kogure, Konishi and Itoh (2015) built an intelligent tutoring system called Intelligent Practice Supporting System (IPSS) with the purpose of improving the teaching-learning conditions in chemistry courses through the personalization of the contents.

The use of web applications in the educational field increases the motivation of students during the performance of the school activities (Zeivots \& Schuck, 2018). For example, Salas-Rueda and Salas-Silis (2018) used the Logic.ly simulator in the classroom in order to facilitate the educational process on mathematics and increase motivation of the students.

Several authors (e.g., Gauthier \& Jenkinson, 2018; Ke, 2014; Yeh, Chang \& Chen, 2019) have built web applications to facilitate the teaching-learning process. Yeh, Chang and Chen (2019) built a digital game to improve educational conditions through interaction, rewards and feedbacks. In the field of biology, Gauthier and Jenkinson (2018) designed and implemented a web application to improve the assimilation of knowledge and development of skills about molecular environments. 
Daradoumis, Marques-Puig, Arguedas and Calvet-Liñan (2019) designed a web tool to improve the performance of students in the field of information technology through the personalization of content. Also, Ke (2014) built an application to facilitate the teaching-learning process about mathematics at the basic educational level.

Finally, technology is modifying the activities carried out in formal and informal education contexts (Chorana, Lakhdari, Cherroun, \& Oulad-Naoui, 2015). For example, the creation of web applications facilitates the assimilation of knowledge, allows the development of skills and increases the motivation of students during the learning process (Gauthier \& Jenkinson, 2018; Yeh, Chang, \& Chen, 2019).

\section{METHOD}

This quantitative research aims to analyze the impact of WAEPCI in the teaching-learning process about Financial Mathematics through the machine learning and data science. WAEPCI presents the calculation of the Compound Interest and Compound Amount over a period of four years by means of the data simulation.

\section{Participants}

The sample consists of 46 students who studied the Financial Mathematics course in a Mexican university during the 2017 school year. The participants, 26 women and $20 \mathrm{men}$, attended the careers of Administration $(n=20,43.48 \%)$, Marketing $(n=10,21.74 \%)$ and Commerce $(n=16,34.78 \%)$.

\section{Procedure}

The procedure began with the design and construction of WAEPCI through the PHP programming language. Figure 1 shows the data requested by WAEPCI (Capital and Interest rate).
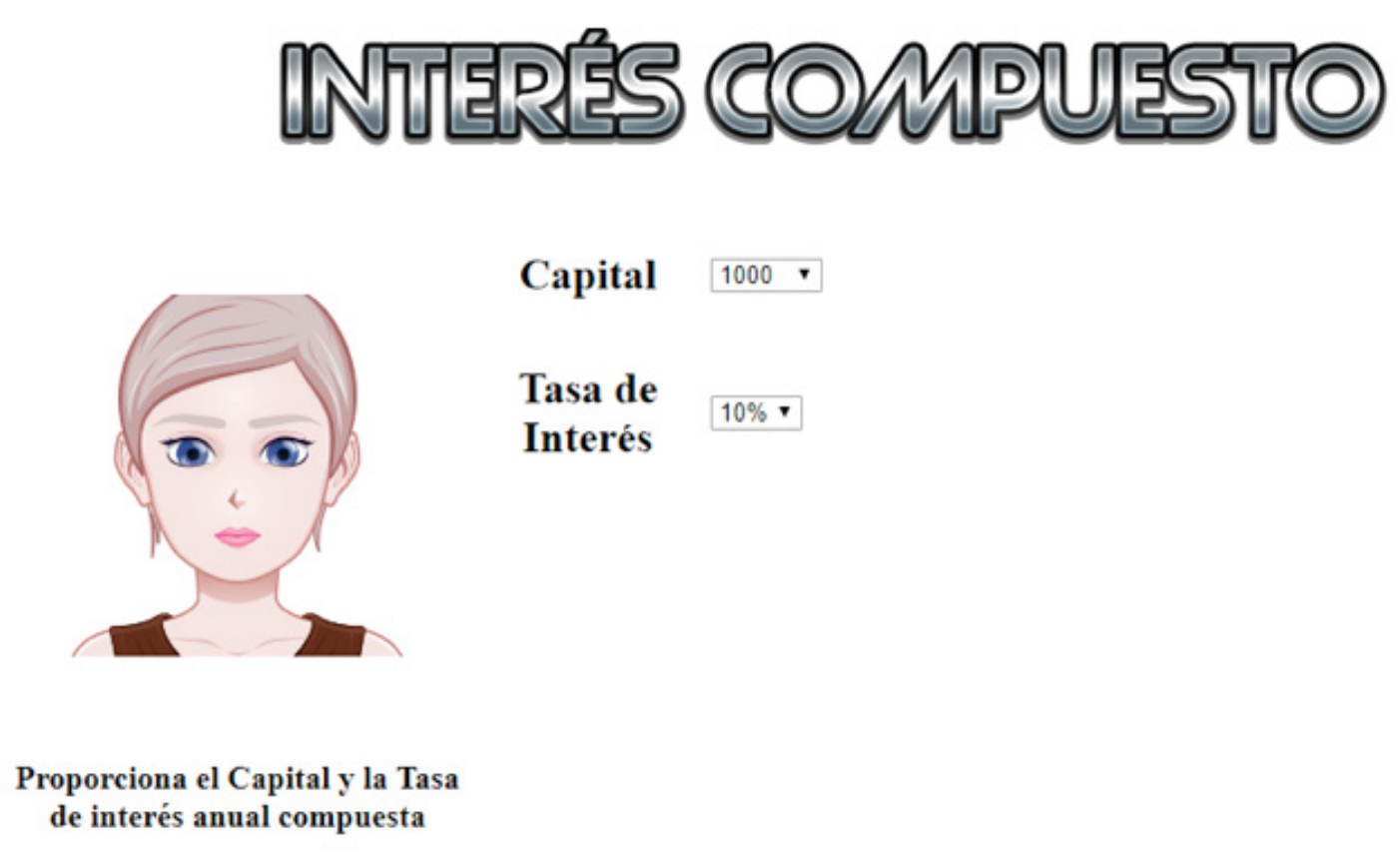

\section{Capital 1000 ?}

Tasa de

Interés $10 \%$ -

\section{conuturis}

Figure 1. Homepage of WAEPCI

WAEPCI is available at the following web address: http://sistemasusables.com/matfin/sistemal/inicio.html Figure 2 shows the data simulation of the Compound Interest and Compound Amount in WAEPCI for the year 1. 

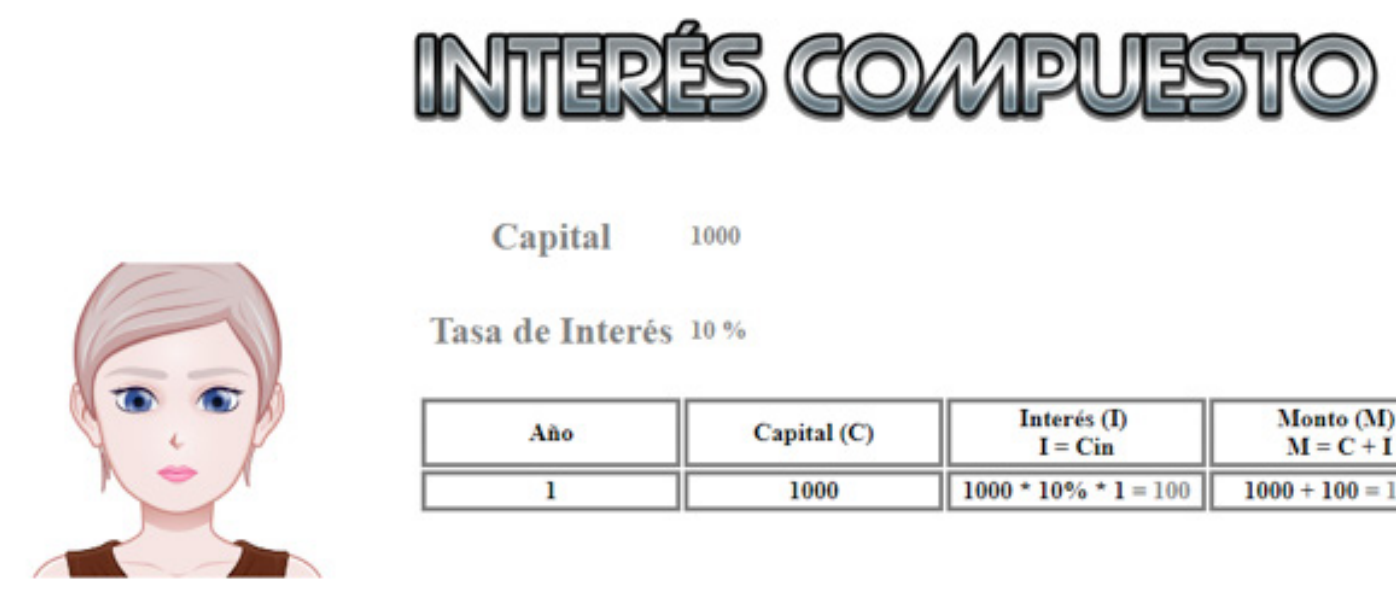

Capital $\quad 1000$

Tasa de Interés $10 \%$

\begin{tabular}{|c||c||c||c|}
\hline Aǹo & Capital (C) & $\begin{array}{c}\text { Interés (I) } \\
\mathrm{I}=\mathbf{C i n}\end{array}$ & $\begin{array}{c}\text { Monto }(\mathrm{M}) \\
\mathbf{I}=\mathbf{C}+\mathbf{I}\end{array}$ \\
\hline \hline 1 & 1000 & $1000 * 10 \% * 1=100$ & $1000+100=1100$ \\
\hline
\end{tabular}

Interés Compuesto en el Año 1

\section{conuturis}

Figure 2. Compound Interest and Compound Amount in WAEPCI for the year 1

WAEPCI presents the calculation of the Compound Interest and Compound Amount for the year 2.
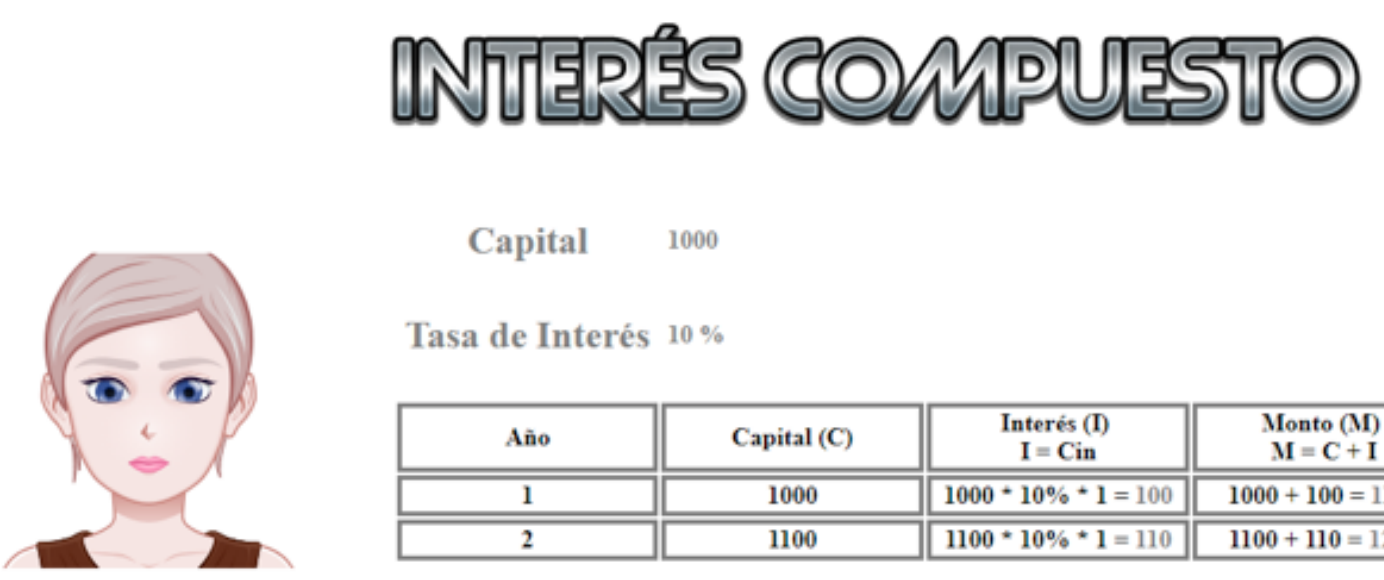

$$
\text { Capital } \quad 1000
$$

Tasa de Interés $10 \%$

\begin{tabular}{|c||c||c||c|}
\hline Año & Capital (C) & $\begin{array}{c}\text { Interés (I) } \\
\mathbf{I}=\text { Cin }\end{array}$ & $\begin{array}{c}\text { Monto }(\mathrm{M}) \\
\mathbf{M}=\mathbf{C}+\mathbf{I}\end{array}$ \\
\hline \hline 1 & 1000 & $1000^{*} 10^{*} \mathrm{I}=100$ & $1000+100=1100$ \\
\hline \hline 2 & 1100 & $1100^{*} 10 \%^{*} 1=110$ & $1100+110=1210$ \\
\hline
\end{tabular}

Interés Compuesto en el Año 2

\section{Conutriens}

Figure 3. Compound Interest and Compound Amount in WAEPCI for the year 2

WAEPCI presents the data simulation on the Compound Interest and Compound Amount for the year 3 (See Figure 4). 


\section{WNitg:}

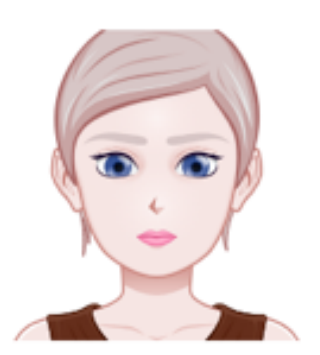

\section{Capital $\quad 1000$}

Tasa de Interés $10 \%$

\begin{tabular}{|c|c|c||c|}
\hline Año & Capital $(\mathbf{C})$ & $\begin{array}{c}\text { Interés (I) } \\
\mathbf{I}=\mathbf{C i n}\end{array}$ & $\begin{array}{c}\text { Monto (M) } \\
\mathbf{M}=\mathbf{C}+\mathbf{I}\end{array}$ \\
\hline \hline 1 & 1000 & $1000 * 10 \% * 1=100$ & $1000+100=1100$ \\
\hline \hline 2 & 1100 & $1100 * 10 \% * 1=110$ & $1100+110=1210$ \\
\hline \hline 3 & 1210 & $1210 * 10 \% * 1=121$ & $1210+121=1331$ \\
\hline
\end{tabular}

Interés Compuesto en el Año 3

\section{Coñtivas}

Figure 4. Compound Interest and Compound Amount in WAEPCI for the year 3

Finally, Figure 5 shows the calculation of the Compound Interest and Compound Amount in WAEPCI for the year 4 .
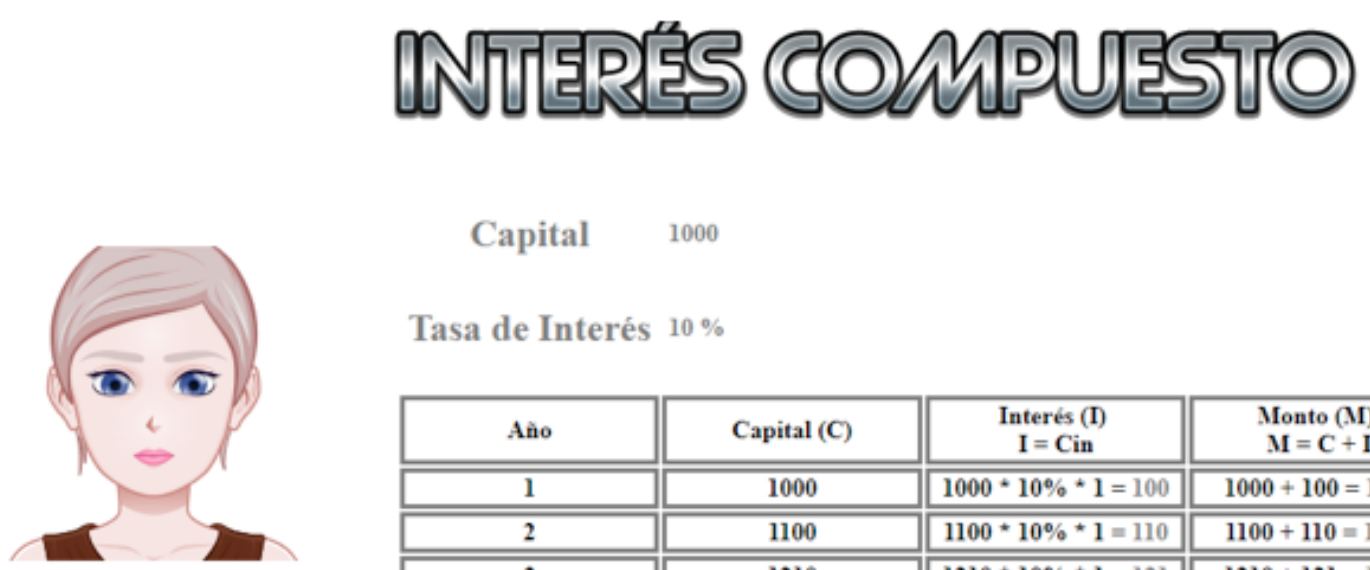

Capital $\quad 1000$

Tasa de Interés $10 \%$

\begin{tabular}{|c||c|c||c|}
\hline \multirow{2}{*}{ Año } & Capital (C) & $\begin{array}{c}\text { Interés (I) } \\
\mathbf{I}=\text { Cin }\end{array}$ & $\begin{array}{c}\text { Monto (M) } \\
\mathbf{M}=\mathbf{C}+\mathbf{I}\end{array}$ \\
\hline \hline 1 & 1000 & $1000 * 10 \% * 1=100$ & $1000+100=1100$ \\
\hline \hline 2 & 1100 & $1100 * 10 \% * 1=110$ & $1100+110=1210$ \\
\hline \hline 3 & 1210 & $1210 * 10 \% * 1=121$ & $1210+121=1331$ \\
\hline \hline 4 & 1331 & $1331 * 10 \% * 1=133.1$ & $1331+133.1=1464.1$ \\
\hline
\end{tabular}

Interés Compuesto en el Año 4

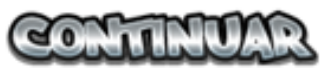

Figure 5. Compound Interest and Compound Amount in WAEPCI for the year 4

Figure 6 shows the technological acceptance model used in this quantitative research. 


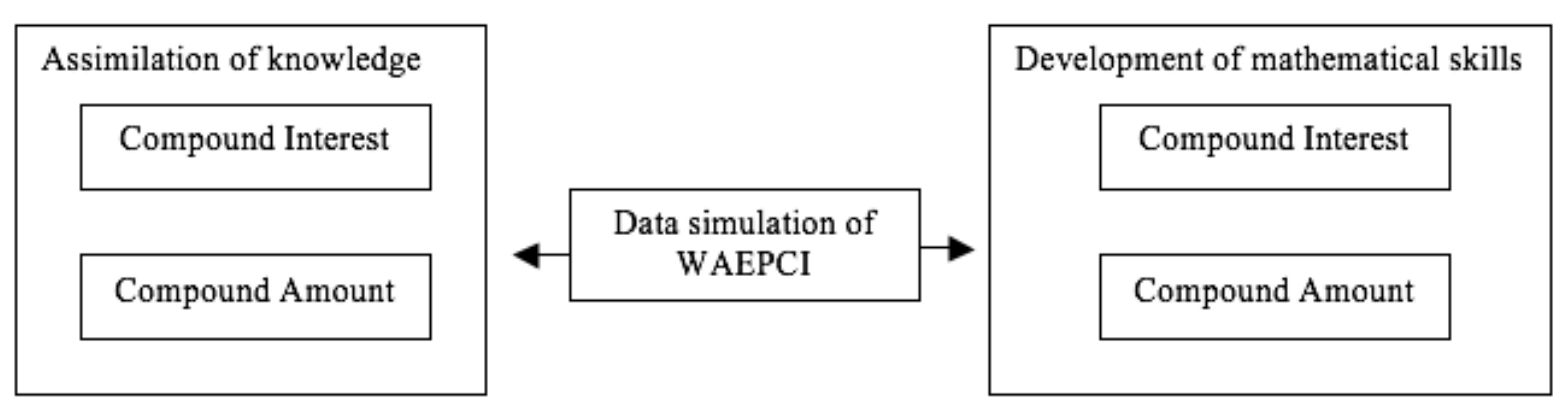

Figure 6. Technological acceptance model of WAEPCI

The research hypotheses about the impact of WAEPCI in the teaching-learning process are:

- Hypothesis 1 (H1): Data simulation of WAEPCI positively influences the assimilation of knowledge about the Compound Interest

- Hypothesis 2 (H2): Data simulation of WAEPCI positively influences the assimilation of knowledge about the Compound Amount

- Hypothesis 3 (H3): Data simulation of WAEPCI positively influences the development of mathematical skills about the Compound Interest

- Hypothesis 4 (H4): Data simulation of WAEPCI positively influences the development of mathematical skills about the Compound Amount

Information about the career, age, sex of the students, data simulation of WAEPCI and the teachinglearning process is used during the construction of the predictive models (decision tree technique).

The predictive models on the use of WAEPCI in the teaching-learning process are:

- Predictive model 1 on WAEPCI and assimilation of knowledge (Compound Interest)

- Predictive model 2 on WAEPCI and assimilation of knowledge (Compound Amount)

- Predictive model 3 on WAEPCI and development of mathematical skills (Compound Interest)

- Predictive model 4 on WAEPCI and development of mathematical skills (Compound Amount)

\section{Data Analysis}

The Rapidminer tool allows the calculation of the machine learning (linear regression) and construction of the predictive models by means of the decision tree technique (data science). Machine learning uses the training section to calculate the linear regressions and evaluate the hypotheses of this research, that is, 50\% ( $\mathrm{n}=23$ students), $60 \%$ ( $\mathrm{n}=27$ students) and $70 \%(\mathrm{n}=32$ students) of the sample allow knowing the impact of WAEPCI in the teaching-learning process. On the other hand, the evaluation section with $50 \%(\mathrm{n}=23$ students), $40 \%$ ( $\mathrm{n}=19$ students) and 30\% ( $\mathrm{n}=14$ students) of the sample allows identifying the accuracy of these linear regressions by means of the calculation on the squared error. (See Figure 7). 


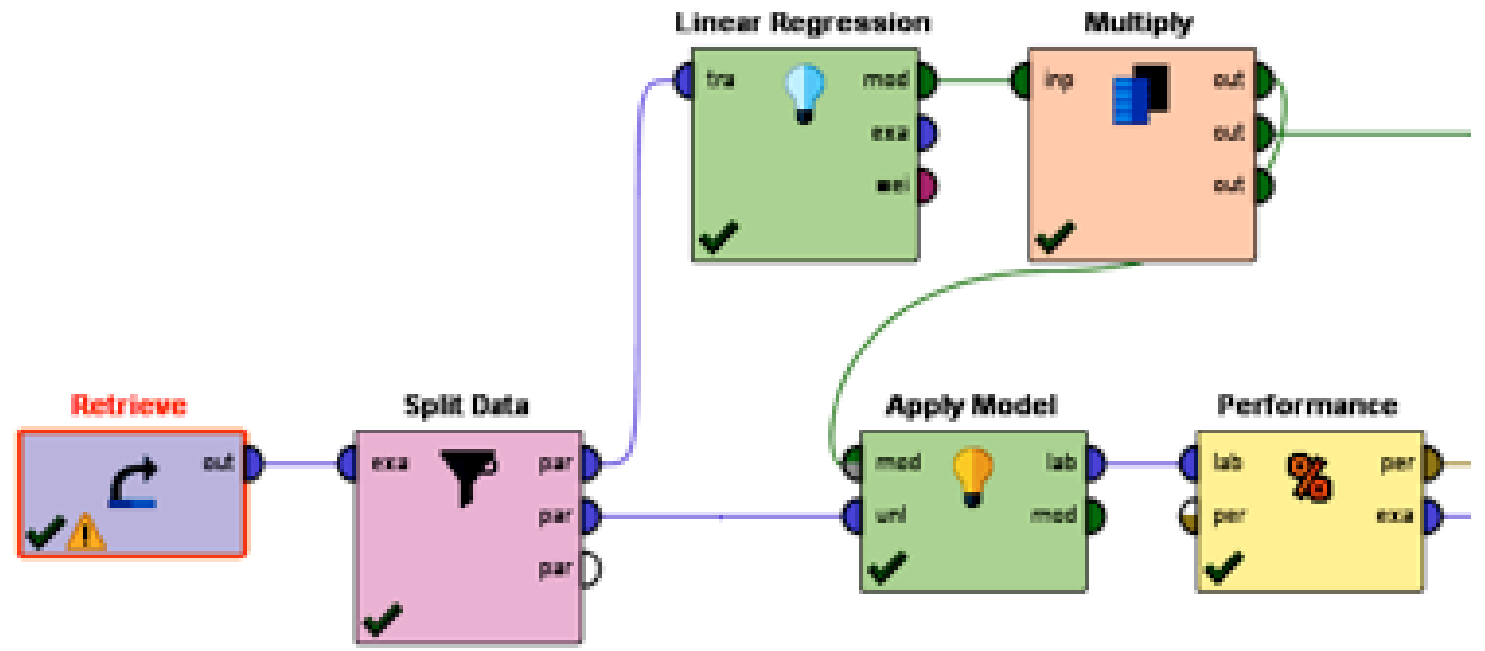

Figure 7. Machine learning in the Rapidminer tool

Figure 8 shows the use of the Rapidminer tool for the construction of predictive models by means of the decision tree technique.

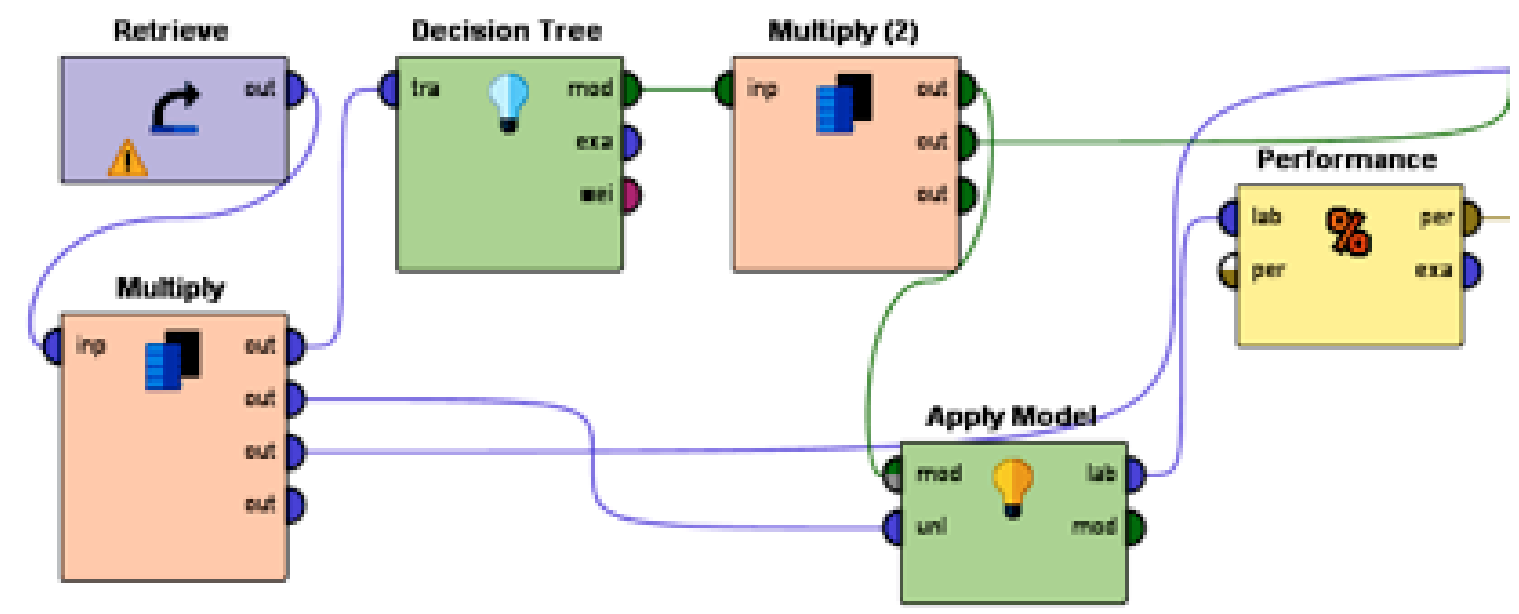

Figure 8. Predictive models in the Rapidminer tool

\section{Data Collection}

Table 1 shows the measurement instrument used for the collection of data about the use of WAEPCI in the teaching-learning process. 
Table 1. Questionnaire

\begin{tabular}{|c|c|c|c|c|c|}
\hline Variable & Dimension & Question & Answer & $\mathbf{n}$ & $\%$ \\
\hline \multirow{15}{*}{ Profile of student } & \multirow{4}{*}{ Career } & 1. Indicate your career & & & \\
\hline & & & Administration & 20 & $43.48 \%$ \\
\hline & & & Commerce & 16 & $34.78 \%$ \\
\hline & & & Marketing & 10 & $21.74 \%$ \\
\hline & \multirow{3}{*}{ Sex } & 2. Indicate your sex & & & \\
\hline & & & Man & 20 & $43.48 \%$ \\
\hline & & & Woman & 26 & $56.52 \%$ \\
\hline & \multirow{8}{*}{ Age } & 3. Indicate your age & & & \\
\hline & & & 18 years & 4 & $8.70 \%$ \\
\hline & & & 19 years & 20 & $43.48 \%$ \\
\hline & & & 20 years & 14 & $30.43 \%$ \\
\hline & & & 21 years & 4 & $8.70 \%$ \\
\hline & & & 22 years & 4 & $8.70 \%$ \\
\hline & & & 23 years & 0 & $0.00 \%$ \\
\hline & & & 24 years & 0 & $0.00 \%$ \\
\hline \multirow{4}{*}{ WAEPCI } & \multirow{4}{*}{$\begin{array}{c}\text { Data } \\
\text { simulation }\end{array}$} & 4. Data simulation of WAEPCI is & & & \\
\hline & & & Excellent (1) & 30 & $65.22 \%$ \\
\hline & & & Good (2) & 14 & $30.43 \%$ \\
\hline & & & $\operatorname{Bad}(3)$ & 2 & $4.35 \%$ \\
\hline \multirow{6}{*}{$\begin{array}{l}\text { Assimilation of } \\
\text { knowledge }\end{array}$} & \multirow{3}{*}{$\begin{array}{l}\text { Compound } \\
\text { Interest }\end{array}$} & \multirow{3}{*}{$\begin{array}{l}\text { 5. The use of WAEPCI influences the } \\
\text { assimilation of knowledge about the } \\
\text { Compound Interest }\end{array}$} & Too much (1) & 29 & $63.04 \%$ \\
\hline & & & Much (2) & 13 & $28.26 \%$ \\
\hline & & & Little (3) & 4 & $8.70 \%$ \\
\hline & \multirow{3}{*}{$\begin{array}{l}\text { Compound } \\
\text { Amount }\end{array}$} & \multirow{3}{*}{$\begin{array}{l}\text { 6. The use of WAEPCI influences the } \\
\text { assimilation of knowledge about the } \\
\text { Compound Amount. }\end{array}$} & Too much (1) & 30 & $65.22 \%$ \\
\hline & & & Much (2) & 12 & $26.09 \%$ \\
\hline & & & Little (3) & 4 & $8.70 \%$ \\
\hline \multirow{6}{*}{$\begin{array}{l}\text { Development of } \\
\text { mathematical skills }\end{array}$} & \multirow{3}{*}{$\begin{array}{l}\text { Compound } \\
\text { Interest }\end{array}$} & \multirow{3}{*}{$\begin{array}{l}\text { 7. The use of the WAEPCI influences } \\
\text { the development of mathematical } \\
\text { skills about the Compound Interest }\end{array}$} & Too much (1) & 38 & $82.61 \%$ \\
\hline & & & Much (2) & 6 & $13.04 \%$ \\
\hline & & & Little (3) & 2 & $4.35 \%$ \\
\hline & \multirow{3}{*}{$\begin{array}{l}\text { Compound } \\
\text { Amount }\end{array}$} & \multirow{3}{*}{$\begin{array}{l}\text { 8. The use of WAEPCI influences the } \\
\text { development of mathematical skills } \\
\text { about the Compound Amount }\end{array}$} & Too much (1) & 31 & $67.39 \%$ \\
\hline & & & Much (2) & 13 & $28.26 \%$ \\
\hline & & & Little (3) & 2 & $4.35 \%$ \\
\hline
\end{tabular}

The data collection was done at the end of the Compound interest unit in the 2017 school year. Also, Cronbach's alpha for the Assimilation of knowledge (0.628) and Development of mathematical skills (0.824) are greater than the value of 0.620 .

\section{RESULTS}

Data simulation of WAEPCI positively influences the assimilation of knowledge and development of mathematical skills about the Compound Interest and Compound Amount (See Table 2). 
Table 2. Results of the machine learning (linear regression)

\begin{tabular}{|c|c|c|c|c|}
\hline Hypothesis & Training & Linear regression & Conclusion & Squared error \\
\hline \multirow{3}{*}{$\begin{array}{l}\mathrm{H} 1: \text { WAEPCI } \rightarrow \text { Assimilation of } \\
\text { knowledge about the Compound } \\
\text { Interest }\end{array}$} & $50 \%$ & $y=0.886 x+0.250$ & Accepted: 0.886 & 0.132 \\
\hline & $60 \%$ & $y=0.909 x+0.197$ & Accepted: 0.909 & 0.163 \\
\hline & $70 \%$ & $y=0.930 x+0.160$ & Accepted: 0.930 & 0.207 \\
\hline \multirow{3}{*}{$\begin{array}{l}\mathrm{H} 2: \text { WAEPCI } \rightarrow \text { Assimilation of } \\
\text { knowledge about the Compound } \\
\text { Amount }\end{array}$} & $50 \%$ & $y=0.721 x+0.312$ & Accepted: 0.721 & 0.215 \\
\hline & $60 \%$ & $y=0.744 x+0.283$ & Accepted: 0.744 & 0.265 \\
\hline & $70 \%$ & $y=0.743 x+0.360$ & Accepted: 0.743 & 0.165 \\
\hline \multirow{3}{*}{$\begin{array}{l}\mathrm{H} 3: \text { WAEPCI } \rightarrow \text { Development of } \\
\text { mathematical skills about the } \\
\text { Compound Interest }\end{array}$} & $50 \%$ & $y=0.647 x+0.375$ & Accepted: 0.647 & 0.179 \\
\hline & $60 \%$ & $y=0.559 x+0.506$ & Accepted: 0.559 & 0.148 \\
\hline & $70 \%$ & $y=0.677 x+0.360$ & Accepted: 0.677 & 0.183 \\
\hline \multirow{3}{*}{$\begin{array}{l}\text { H4: WAEPCI } \rightarrow \text { Development of } \\
\text { mathematical skills about the } \\
\text { Compound Amount }\end{array}$} & $50 \%$ & $y=0.664 x+0.437$ & Accepted: 0.664 & 0.209 \\
\hline & $60 \%$ & $y=0.629 x+0.444$ & Accepted: 0.629 & 0.240 \\
\hline & $70 \%$ & $y=0.693 x+0.400$ & Accepted: 0.693 & 0.220 \\
\hline
\end{tabular}

\section{Assimilation of Knowledge}

The use of WAEPCI influences too much $(\mathrm{n}=29,63.04 \%)$, much $(\mathrm{n}=13,28.26 \%)$ and little $(\mathrm{n}=4,8.70 \%)$ the assimilation of knowledge about the Compound Interest (See Table 1). Also, the results of machine learning (linear regression) with 50\% (0.886), 60\% (0.909) and 70\% (0.930) of training indicate that hypothesis 1 is accepted (See Table 2). Therefore, data simulation of WAEPCI positively influences the assimilation of knowledge about the Compound Interest.

Figure 9 shows the predictive model 1 on the use of WAEPCI in the teaching-learning process. For example, if the student considers that data simulation of WAEPCI is good, is a man and has an age $>19.5$ years then the use of WAEPCI influences much the assimilation of knowledge about the Compound Interest.

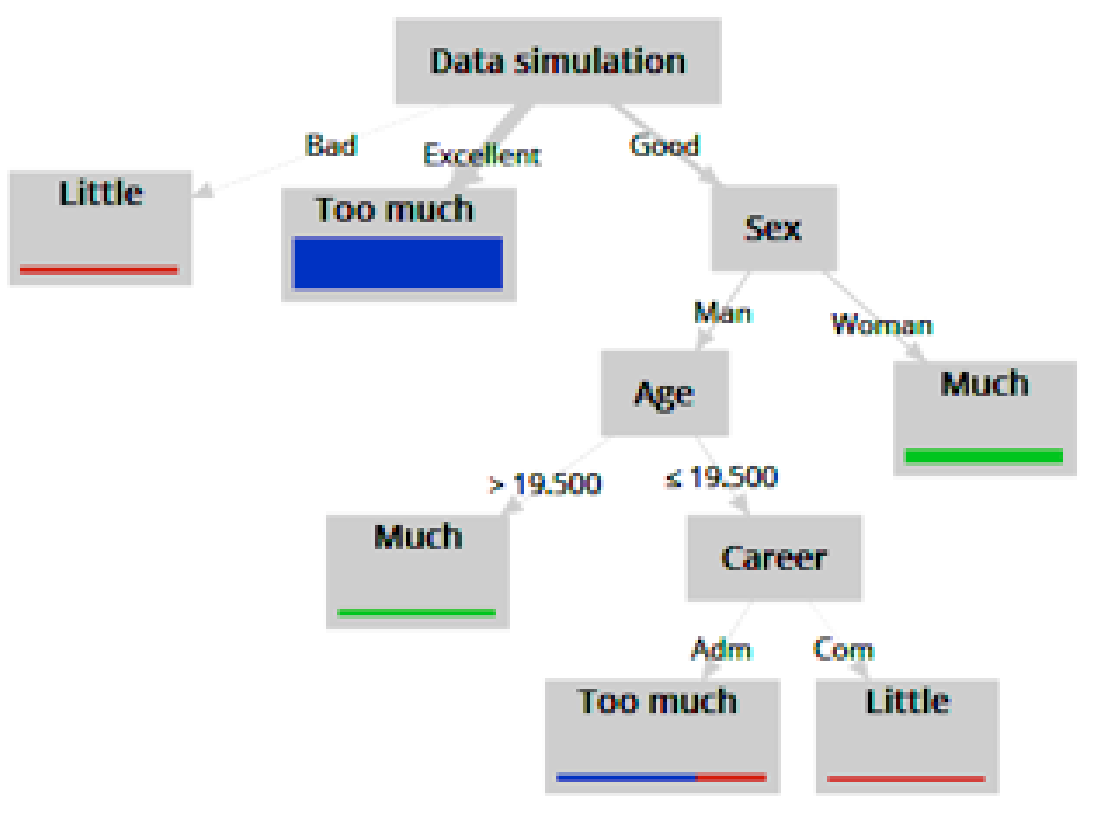

Figure 9. Predictive model 1 on the use of WAEPCI 
The predictive model 1 has the accuracy of $97.83 \%$ and presents 6 conditions on the use of WAEPCI (See Table 3). For example, if the student considers that data simulation of WAEPCI is good and is a woman then the use of WAEPCI influences much the assimilation of knowledge about the Compound Interest.

Table 3. Conditions of the predictive model 1

\begin{tabular}{cccccc}
\hline No. & $\begin{array}{c}\text { Data simulation } \\
\text { of WAEPCI }\end{array}$ & Career & Sex & Age & $\begin{array}{c}\text { Assimilation of knowledge } \\
\text { (Compound interest) }\end{array}$ \\
\hline 1 & Good & - & Man & $>19.5$ years & Much \\
2 & Good & Administration & Man & $\leq 19.5$ years & Too much \\
3 & Good & Commerce & Man & $\leq 19.5$ years & Little \\
4 & Good & - & Woman & - & Much \\
5 & Excellent & - & - & - & Too much \\
6 & Bad & - & - & - & Little \\
\hline
\end{tabular}

The use of WAEPCI influences too much $(\mathrm{n}=30,65.22 \%)$, much $(\mathrm{n}=12,26.09 \%)$ and little $(\mathrm{n}=4,8.70 \%)$ the assimilation of knowledge about the Compound Amount (See Table 1). Also, the results of machine learning with $50 \%(0.721), 60 \%(0.744)$ and $70 \%(0.743)$ of training indicate that hypothesis 2 is accepted (See Table 2). Therefore, data simulation of WAEPCI positively influences the assimilation of knowledge about the Compound Amount. Figure 10 shows the predictive model 2 on the use of WAEPCI in the teaching-learning process. For example, if the student considers that data simulation of WAEPCI is good, is a woman and takes career of the Administration then the use of WAEPCI influences too much the assimilation of knowledge about the Compound Amount.

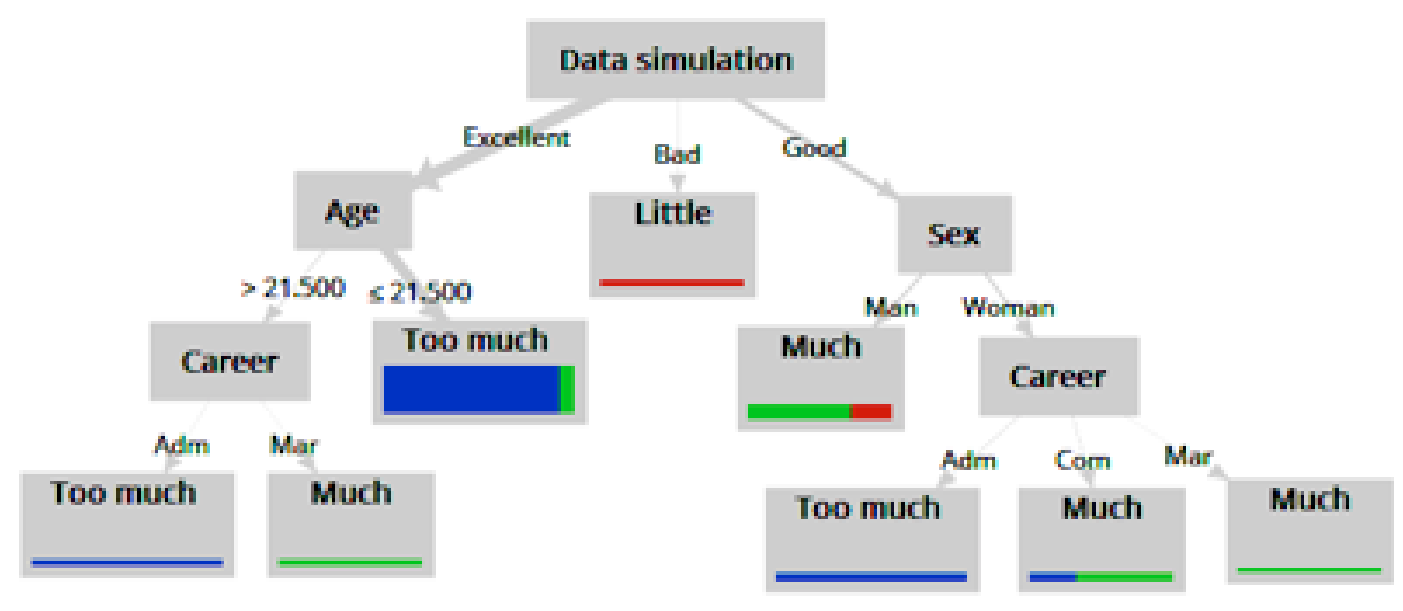

Figure 10. Predictive model 2 on the use of WAEPCI

The predictive model 2 has the accuracy of $89.13 \%$ and presents 8 conditions on the use of WAEPCI (See Table 4). For example, if the student considers that data simulation of WAEPCI is good and is a man then the use of WAEPCI influences much the assimilation of knowledge about the Compound Amount. 
Table 4. Conditions of the predictive model 2

\begin{tabular}{cccccc}
\hline No. & $\begin{array}{c}\text { Data simulation } \\
\text { of WAEPCI }\end{array}$ & Career & Sex & Age & $\begin{array}{c}\text { Assimilation of knowledge } \\
\text { (Compound Amount) }\end{array}$ \\
\hline 1 & Good & - & Man & - & Much \\
2 & Good & Administration & Woman & - & Too much \\
3 & Good & Commerce & Woman & - & Much \\
4 & Good & Marketing & Woman & - & Much \\
5 & Bad & - & - & - & Little \\
6 & Excellent & Administration & - & $>21.5$ years & Too much \\
7 & Excellent & Marketing & - & $>21.5$ years & Much \\
8 & Excellent & - & - & $\leq 21.5$ years & Too much \\
\hline
\end{tabular}

\section{Development of Mathematical Skills}

The use of the WAEPCI influences too much ( $\mathrm{n}=38,82.61 \%)$, much $(\mathrm{n}=6,13.04 \%)$ and little $(\mathrm{n}=2,4.35 \%)$ the development of mathematical skills about the Compound Interest (See Table 1). Also, the results of machine learning with 50\% (0.647), 60\% (0.559) and 70\% (0.677) of training indicate that hypothesis 3 is accepted (See Table 2). Therefore, data simulation of WAEPCI positively influences the development of mathematical skills about the Compound Interest.

Figure 11 shows the predictive model 3 on the use of WAEPCI in the teaching-learning process. For example, if the student considers that data simulation of WAEPCI is good, is a woman and takes the career of Commerce then the use of the WAEPCI influences too much the development of mathematical skills about the Compound Interest.

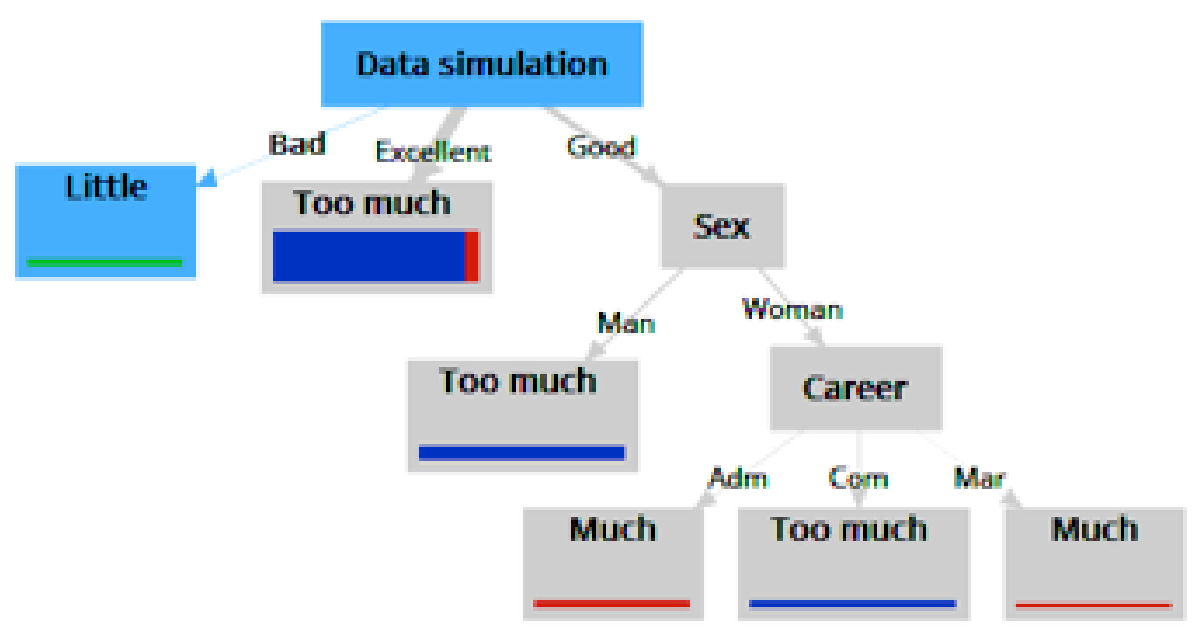

Figure 11. Predictive model 3 on the use of WAEPCI

The predictive model 3 has the accuracy of $95.65 \%$ and presents 6 conditions on the use of WAEPCI (See Table 5). For example, if the student considers that data simulation of WAEPCI is good and is man then the use of the WAEPCI influences too much the development of mathematical skills about the Compound Interest. 
Table 5. Conditions of the predictive model 3

\begin{tabular}{cccccc}
\hline No. & $\begin{array}{c}\text { Data simulation of } \\
\text { WAEPCl }\end{array}$ & Career & Sex & Age & $\begin{array}{c}\text { Development of } \\
\text { mathematical skills about } \\
\text { Compound Interest }\end{array}$ \\
\hline 1 & Good & - & Man & - & Too much \\
2 & Good & Administration & Woman & - & Much \\
3 & Good & Commerce & Woman & - & Too much \\
4 & Good & Marketing & Woman & - & Much \\
5 & Excellent & - & - & - & Too much \\
6 & Bad & - & - & - & Little \\
\hline
\end{tabular}

The use of WAEPCI influences too much $(\mathrm{n}=31,67.39 \%)$, much $(\mathrm{n}=13,28.26 \%)$ and little $(\mathrm{n}=2,4.35 \%)$ the development of mathematical skills about the Compound Amount (See Table 1). Also, the results of machine learning with 50\% (0.664), 60\% (0.629) and 70\% (0.693) of training indicate that hypothesis 4 is accepted (See Table 2). Therefore, data simulation of WAEPCI positively influences the development of mathematical skills about the Compound Amount.

Figure 12 shows the predictive model 4 on the use of WAEPCI in the teaching-learning process. For example, if the student considers that data simulation of WAEPCI is good, is a man and takes the career of Commerce then the use of WAEPCI influences too much the development of mathematical skills about the Compound Amount.

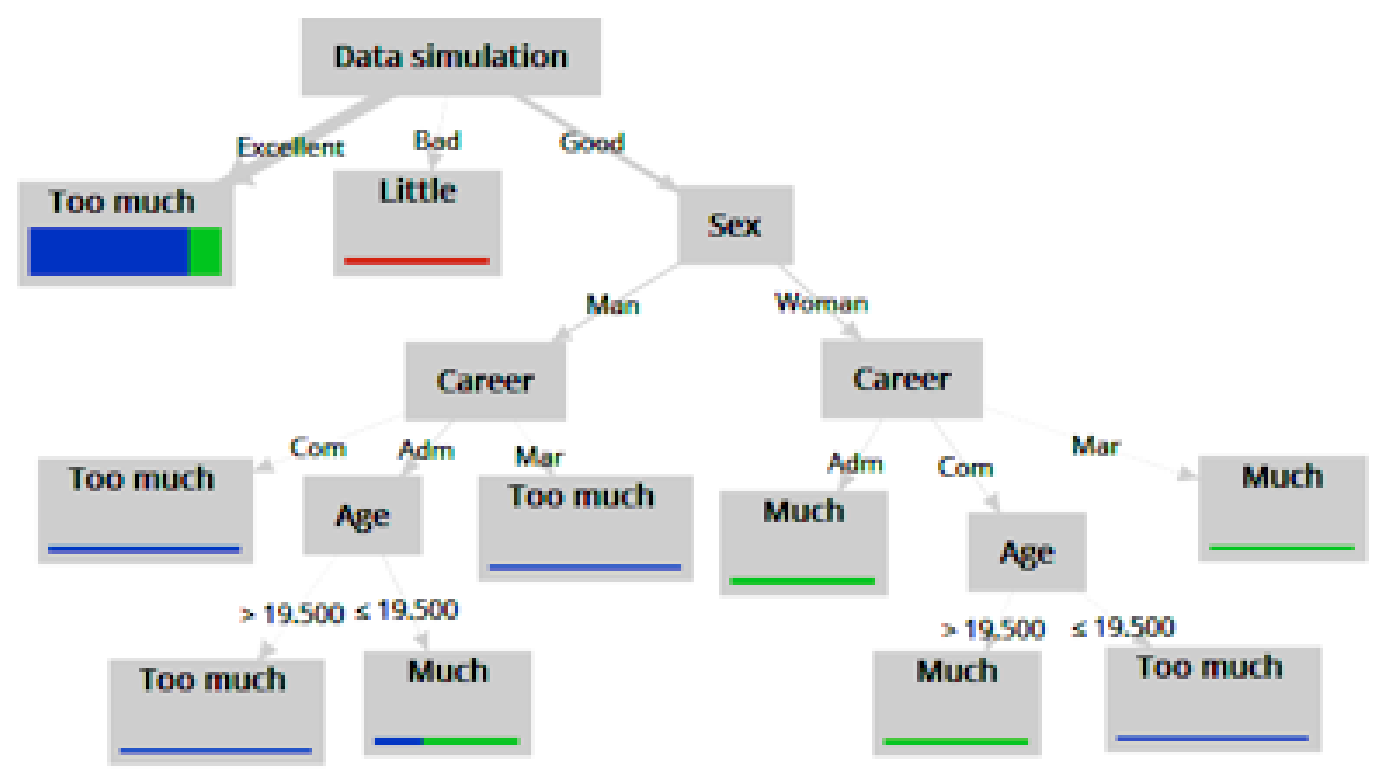

Figure 12. Predictive model 4 on the use of WAEPCI

The predictive model 4 has the accuracy of $86.96 \%$ and presents 10 conditions on the use of WAEPCI (See Table 6). For example, if the student considers that data simulation of WAEPCI is good, is a man and takes the career of Marketing then the use of WAEPCI influences too much the development of mathematical skills about the Compound Amount. 
Table 6. Conditions of the predictive model 4

\begin{tabular}{cccccc}
\hline No. & $\begin{array}{c}\text { Data simulation } \\
\text { of WAEPCI }\end{array}$ & Career & Sex & Age & $\begin{array}{c}\text { Development of } \\
\text { mathematical skills about the } \\
\text { Compound Amount }\end{array}$ \\
\hline 1 & Good & Commerce & Man & - & Too much \\
2 & Good & Administration & Man & $>19.5$ years & Too much \\
3 & Good & Administration & Man & $\leq 19.5$ years & Much \\
4 & Good & Marketing & Man & - & Too much \\
5 & Good & Administration & Woman & - & Much \\
6 & Good & Commerce & Woman & $>19.5$ years & Much \\
7 & Good & Commerce & Woman & $\leq 19.5$ years & Too much \\
8 & Good & Marketing & Woman & - & Much \\
9 & Excellent & - & - & - & Too much \\
10 & Bad & - & - & - & Little \\
\hline
\end{tabular}

\section{DISCUSSION}

The design, construction, use and implementation of web applications allow updating school activities inside and outside the classroom (Alderete, 2017; Barclay, Donalds, \& Osei-Bryson, 2018; Jong, Sotiriou, $\&$ Gillet, 2014). For example, WAEPCI presents the calculation of the Compound Interest and Compound Amount over a period of four years by means of the data simulation.

\section{Assimilation of Knowledge}

The results of the machine learning for the Hypothesis 1 are greater than the value of 0.886 . Therefore, data simulation of WAEPCI positively influences the assimilation of knowledge about the Compound Interest.

Also, the predictive model 1 presents 6 conditions on the use of WAEPCI in the teaching-learning process. For example, if the student considers that data simulation of WAEPCI is good, is a man and has an age > 19.5 years then the use of WAEPCI influences much the assimilation of knowledge about the Compound Interest.

On the other hand, the results of the machine learning for the Hypothesis 2 are greater than the value of 0.720. Therefore, data simulation of WAEPCI positively influences the assimilation of knowledge about the Compound Amount.

Also, the predictive model 2 presents 8 conditions on the use of WAEPCI in the teaching-learning process. For example, if the student considers that data simulation of WAEPCI is good, is a woman and takes career of the Administration then the use of WAEPCI influences too much the assimilation of knowledge about the Compound Amount. In fact, data simulation of WAEPCI has more influence on the assimilation of knowledge about the Compound Interest.

\section{Development of Mathematical Skills}

Several authors (e.g., Radovic, Maric, \& Passey, 2019; Willis, Lynch, Fradale, \& Yeigh, 2019) explain that technological tools facilitate the development of skills in the educational field. The results of the machine learning for the Hypothesis 3 are greater than the value of 0.558 . Therefore, data simulation of WAEPCI positively influences the development of mathematical skills about the Compound Interest.

Also, the predictive model 3 presents 6 conditions on the use of WAEPCI in the teaching-learning process. For example, if the student considers that data simulation of WAEPCI is good, is a woman and takes the career of Commerce then the use of the WAEPCI influences too much the development of mathematical skills about the Compound Interest. 
On the other hand, the results of the machine learning for the Hypothesis 4 are greater than the value of 0.628. Therefore, data simulation of WAEPCI positively influences the development of mathematical skills about the Compound Amount.

Also, the predictive model 4 presents 10 conditions on the use of WAEPCI in the teaching-learning process. For example, if the student considers that data simulation of WAEPCI is good, is a man and takes the career of Commerce then the use of WAEPCI influences too much the development of mathematical skills about the Compound Amount. In fact, data simulation of WAEPCI has more influence on the development of mathematical skills about the Compound Amount.

Finally, technology is modifying the planning and organization of school activities in the 21st century (Kalolo, 2019; Mishra \& Iyer, 2015; Terziyan, Golovianko, \& Shevchenko, 2015). In particular, WAEPCI is a web application that facilitates the educational process on financial mathematics by means of the data simulation.

\section{CONCLUSION}

WAEPCI facilitates the assimilation of knowledge and development of mathematical skills on Compound Interest and Compound Amount. The results of machine learning with $50 \%, 60 \%$ and $70 \%$ of training indicate that WAEPCI positively influences the educational process on financial mathematics.

Data science identified 4 predictive models on the use of WAEPCI in the teaching-learning process through the decision tree technique. The accuracy of these predictive models presents an accuracy higher than $86.90 \%$.

This research recommends the construction of web applications to achieve the active role of students through the data simulation. Also, teachers can incorporate technological tools in and out the classroom in order to develop the competencies of students.

The limitations of this research are the size of the sample and use of WAEPCI in the topics of Compound Interest and Compound Amount. Therefore, future research can build web applications that facilitate the educational process on annuities, amortizations and depreciation. Likewise, teachers can use digital games and web applications in the educational field with the purpose of creating new virtual spaces for learning.

The implications of this research are related to the use of technology in school activities to improve teachinglearning conditions. For example, WAEPCI is a web application that facilitates the assimilation of knowledge and allows the development of mathematical skills on financial mathematics.

Finally, educational institutions can modify the functions and activities of teachers and students through technological tools and media of communication. In particular, WAEPCI transforms the teaching-learning process on financial mathematics through the data simulation on the Compound Interest and Compound Amount.

\section{BIODATA and CONTACT ADDRESSES of AUTHORS}

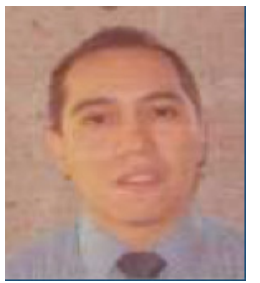

Dr. Ricardo-Adan SALAS-RUEDA is a full time researcher in the Instituto de Ciencias Aplicadas y Tecnologia, Universidad Nacional Autonoma de Mexico. Dr. Ricardo-Adan gained his Ph.D. in New Technologies Design. His academic interest areas are educative technology, web application design, data science, machine learning and neural networks. He has 13 journal articles published in international indexes, 10 international book chapters and 4 international books.

Ricardo-Adan SALAS-RUEDA

Instituto de Ciencias Aplicadas y Tecnologia, Universidad Nacional Autonoma de Mexico

Address: Circuito Exterior S/N, Ciudad Universitaria, 04510, Mexico City, Mexico.

Phone: +5556228601

E-mail: ricardo.salas@icat.unam.mx 


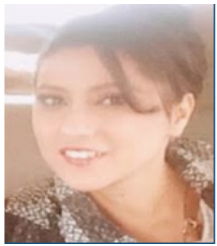

Dr. Erika-Patricia SALAS-RUEDA has gained her Ph.D. in Humanistic studies at Instituto Tecnologico y de Estudios Superiores de Monterrey, Mexico. Her academic interest areas are educative technology, web application design, data science, pedagogy, ICT, machine learning and neural networks. She has 3 journal articles published in international indexes and 1 international book.

\section{Erika-Patricia SALAS-RUEDA}

Instituto Tecnologico y de Estudios Superiores de Monterrey

Address: Maria Auxiliadora 7, Coapa, San Bartolo el Chico, Tlalpan, 14380, Mexico City, Mexico.

Phone: +5514959555

E-mail: serik_patt@hotmail.com

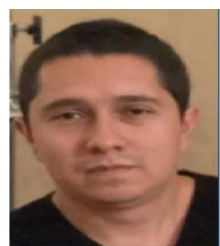

Rodrigo-David SALAS-RUEDA has gained his Bachelor in Administration at Universidad Autonoma Metropolitana. His academic interest areas are educative technology, web application design, data science, pedagogy, ICT, machine learning and neural networks. He has 4 journal articles published in international indexes and 1 international book.

Rodrigo-David SALAS-RUEDA

Universidad Autonoma Metropolitana

Address: Calz. del Hueso 1100, Coapa, Villa Quietud, Coyoacan, 04960, Mexico City, Mexico

Phone: +5532089477

E-mail: rodrigodavidsalas@hotmail.com

\section{REFERENCES}

Alderete, M. V. (2017). Examining the ICT access effect on socioeconomic development: the moderating role of ICT use and skills. Information Technology for Development, 23(1), 42-58.

Ayale-Perez, T. \& Joo-Nagata, J. (2019). The digital culture of students of pedagogy specialising in the humanities in Santiago de Chile. Computers \& Education, 133, 1-12.

Barclay, C., Donalds, C., \& Osei-Bryson, K. M. (2018). Investigating critical success factors in online learning environments in higher education systems in the Caribbean. Information Technology for Development, 24(3), 582-61.

Bdiwi, R., Runz, C., Faiz, S., \& Cherif, A. A. (2019). Smart learning environment: Teacher's role in assessing classroom attention. Research in Learning Technology, 27, 1-14.

Bidarra, J. \& Rusman, E. (2017) Towards a pedagogical model for science education: bridging educational contexts through a blended learning approach. Open Learning: The Journal of Open, Distance and e-Learning, 32(1), 6-20.

Blaine, A. M. (2019). Interaction and presence in the virtual classroom: An analysis of the perceptions of students and teachers in online and blended Advanced Placement courses. Computers \& Education, $132,31-43$.

Carvalho, L. \& Yeoman, P. (2018). Framing learning entanglement in innovative learning spaces: Connecting theory, design and practice. British Educational Research Journal, 44(6), 1120-1137.

Chorana, A., Lakhdari, A., Cherroun, H., \& Oulad-Naoui, S. (2015). XML-based e-assessment system for Office skills in open learning environments. Research and Practice in Technology Enhanced Learning, $10,1-17$.

Daradoumis, T., Marques-Puig, J. M., Arguedas, M., \& Calvet-Liñan, L. (2019). Analyzing students' perceptions to improve the design of an automated assessment tool in online distributed programming. Computers \& Education, 128, 159-170.

Doney, I. (2019). Research into effective gamification features to inform e-learning design. Research in Learning Technology, 27, 1-10. 
Gauthier, A. \& Jenkinson, J. (2018). Designing productively negative experiences with serious game mechanics: Qualitative analysis of game-play and game design in a randomized trial. Computers \& Education, 127, 66-89.

Gezgin, D. M. (2019). The Effect of Mobile Learning Approach on University Students' Academic Success for Database Management Systems Course. International Journal of Distance Education Technologies, 17(1), 15-30.

Herodotou, C., Heiser, S., \& Rienties, B. (2017) Implementing randomised control trials in open and distance learning: a feasibility study. Open Learning: The Journal of Open, Distance and e-Learning, 32(2), 147-162.

Hughes, G. \& Dobbins, C. (2015). The utilization of data analysis techniques in predicting student performance in massive open online courses (MOOCs). Research and Practice in Technology Enhanced Learning, 10, 1-18.

Jack, C. \& Higgins, S. (2019). Embedding educational technologies in early years education. Research in Learning Technology, 27, 1-17.

Jong, T. D., Sotiriou, S., \& Gillet, D. (2014). Innovations in STEM education: the Go-Lab federation of online labs. Smart Learning Environments, 1, 1-16.

Kalolo, J. F. (2019). Digital revolution and its impact on education systems in developing countries. Education and Information Technologies, 24(1), 345-358.

Ke, F. (2014). An implementation of design-based learning through creating educational computer games: A case study on mathematics learning during design and computing. Computers \& Education, 73, 26-39.

Le, N. T. \& Pinkwart, N. (2015). Evaluation of a question generation approach using semantic web for supporting argumentation. Research and Practice in Technology Enhanced Learning, 10, 1-19.

Lee, C., Yeung, A. S., \& Cheung, K. W. (2019). Learner perceptions versus technology usage: A study of adolescent English learners in Hong Kong secondary schools. Computers \& Education, 133, 13-26.

Marcel, F. (2019). Mobile augmented reality learning objects in higher education. Research in Learning Technology, 27, 1-10.

Marshalsey, L. \& Sclater, M. (2018). Supporting students' self-directed experiences of studio learning in Communication Design: The co-creation of a participatory methods process model. Australasian Journal of Educational Technology, 34(6), 65-81.

Mei, B. \& May, L. (2018). Reflective renovation: Insights from a collaborative and active learning space project evaluation. Australasian Journal of Educational Technology, 34(6), 17-26.

Mishra, S. \& Iyer, S. (2015). An exploration of problem posing-based activities as an assessment tool and as an instructional strategy. Research and Practice in Technology Enhanced Learning, 10, 1-19.

Noguchi, Y., Kogure, S., Konishi, T., \& Itoh, Y. (2015). Practice supporting system with related problem set generator based on targeted educational effects. Research and Practice in Technology Enhanced Learning, 10, 1-16.

Radovic, S., Maric, M., \& Passey, D. (2019). Technology enhancing mathematics learning behaviours: Shifting learning goals from producing the right answer to understanding how to address current and future mathematical challenges. Education and Information Technologies, 24(1), 103-126.

Ramadan, R. (2016). Syrians' acceptance of digital lectures: a case study. Open Learning: The Journal of Open, Distance and e-Learning, 31(1), 9-24.

Rooney, D. \& Nystrom, S. (2018). Simulation: A complex pedagogical space. Australasian Journal of Educational Technology, 34(6), 53-64.

Salas-Rueda, R. A. \& Salas-Rueda, R. D. (2019). Impact of the social network Facebook in the higher education process of mathematics considering the science of data. Noesis: Revista de Ciencias Sociales y Humanidades, 28(1), 23-42.

Salas-Rueda, R. A. \& Salas-Silis, J. A. (2018). Logic.ly Simulator. Technological tool to facilitate the teaching-learning process about Mathematics? Revista Dilemas Contemporaneos: Educacion, Politica y Valores, 5(3), 1-25. 
Salas-Rueda, R. A., Salas-Rueda, E. P., Salas-Rueda, R. D., \& Vargas-Perez, Y. M. (2019). Analysis of the Web Application for the Punctual Estimation by means of data science. Revista Dilemas Contemporaneos: Educacion, Politica y Valores, 6(2), 1-25.

Scardamalia, M. \& Bereiter, C. (2014). Smart technology for self-organizing processes. Smart Learning Environments, 1, 1-13.

Spector, J. M. (2014). Conceptualizing the emerging field of smart learning environments. Smart Learning Environments, 1, 1-10.

Terziyan, V., Golovianko, M., \& Shevchenko, O. (2015). Semantic Portal as a Tool for Structural Reform of the Ukrainian Educational System. Information Technology for Development, 21(3), 381-402.

Wang, S. \& Wang, H. (2017) Adoption of open educational resources (OER) textbook for an introductory information systems course. Open Learning: The Journal of Open, Distance and e-Learning, 32(3), 224-235.

Willis, R. L., Lynch, D., Fradale, P., \& Yeigh, T. (2019). Influences on purposeful implementation of ICT into the classroom: An exploratory study of K-12 teachers. Education and Information Technologies, 24(1), 63-77.

Yeh, Y., Chang, H. L., \& Chen, S. Y. (2019). Mindful learning: A mediator of mastery experience during digital creativity game-based learning among elementary school students. Computers \& Education, $132,63-75$.

Yeoman, P. \& Ashmore, N. (2018). Moving from pedagogical challenge to ergonomic challenge: Translating epistemology into the built environment for learning. Australasian Journal of Educational Technology, 34(6), 1-16.

Zeivots, S. \& Schuck, S. (2018). Needs and expectations of a new learning space: Research students' perspectives. Australasian Journal of Educational Technology, 34(6), 27-40. 